\title{
Correction to: "The Cardenolide Glycoside Acovenoside A Affords Protective Activity in Doxorubicin-Induced Cardiotoxicity in Mice."
}

Due to a compositor error, the "received" and "accepted" dates originally published in the paper were incorrect in the above article [Ezzat SM, El Gaafary M, El Sayed AM, Sabry OM, Ali ZY, Hafner S, Schmiech M, Jin L, Syrovets T and Simmet T. (2016) J Pharmacol Exp Ther 358 (2) 262-270. DOI: https://doi.org/10.1124/jpet.116.232652].

The correct dates are as follow:

Received: February 2, 2016. Accepted: May 25, 2016

The published article has been corrected.

The compositor regrets this error and apologizes for any inconvenience it may have caused. 